\section{Wave Runup for Nowshahr Breakwater at Tide and Ebb Scenarios}

Farhad Sakhaee ${ }^{1}$

${ }^{1}$ Parks College of Engineering, Aviation and Technology, Civil Engineering Dept., Saint Louis University, USA

\section{Keywords}

Runup calculations

Tide and ebb,

Breakwater extension,

Cross-sectional-deign.

\begin{abstract}
This study investigates runup design at breakwaters and design criteria under tidal and ebb scenarios for both head and truck of Nowshahr breakwater. First part includes runup height calculations based on shore protection manuals. Based of wave height, frequency, and water depth at the toe runup height has been calculated and Second portion has been dedicated to design of head and truck of Nowshahr port based on Hudson stability formula. Collision of wave and the breakwater head, results in immediate reduction in wave energy. As wave energy propagated gradually decreases when it meets the trunk. The results showed that in both conditions weight of head would be higher than the trunk of breakwater. while, both head and trunk are designed based on high strength materials, but the head has higher degree of importance in terms of design criteria. Hudson formula is responsible for the stability of breakwater structure. Tidal case which considers a non-breaking wave as well as ebb scenario including a breaking wave has been studied to include two extreme conditions occurs to breakwaters. The results showed the higher weight of head is responsible for stability of breakwater at both conditions.
\end{abstract}

\section{Introduction}

are many studies which have applied a high-order finite difference method to investigate wave runup and rundown with depth integration equation(Lynett, Wu et al. 2002) but few talks about ruunnup and its effect on the structure under tidal and ebb conditions. Breakwaters, groins and other coastal offshore structures serve as a protective structure against waves and water crises in order to create a safe environment inside the pool of harbor to facilitate transferring goods and people.(Sakhaee and Khalili 2020) Types of armor for structures could vary between different configurations of concrete blocks such as akmon, cube, tetrapod, acropad, cassho block, dolos and timber as presented in figure 1.Until recent years the only way to mimic and evaluate the wave actions on the breakwater was physical models, but recently computational fluid dynamics enables us to have 2D and 3D analysis before construction.(Dentale, Donnarumma et al. 2014)

Wave reflection and runup have been investigated throughout large scale experimental models.(Muttray, Oumeraci et al. 2007) Estimating the runnup and overtopping rate in breakwaters is a critical design aspect.(Medina 1999) In submerged breakwaters wave runnup height appears behind the center, and as the crown width ratio increases, the wave runup generally decreases.(Hur, Lee et al. 2012) Some experiments has been done on the runnup height of tsunami waves.(İtem, Seyfioglu et al. 2011) A schematic of wave runup as well as approaching wave to a rubble mound breakwater have been presented in Figure 2 a and b. Location of breakwater arms considering Nowshahr port and Caspian Sea and also a cross section of breakwater presented below.(Figure $2 \mathrm{c}$ and d)

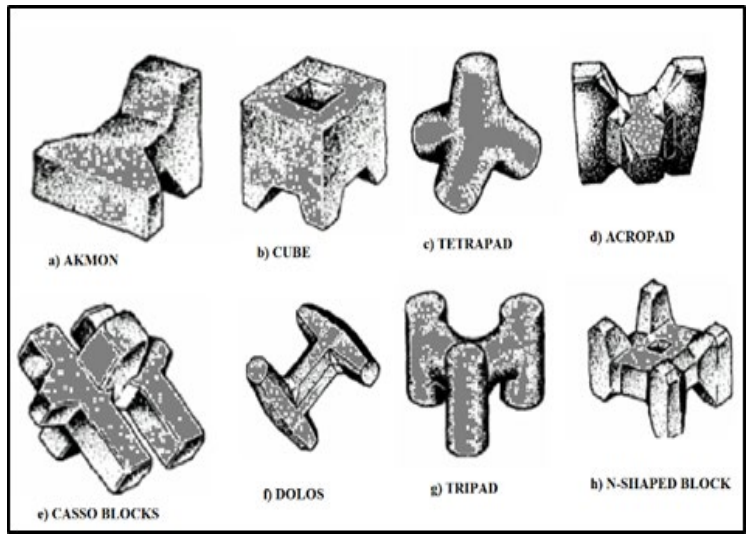

Figure 1. Type of armor stones

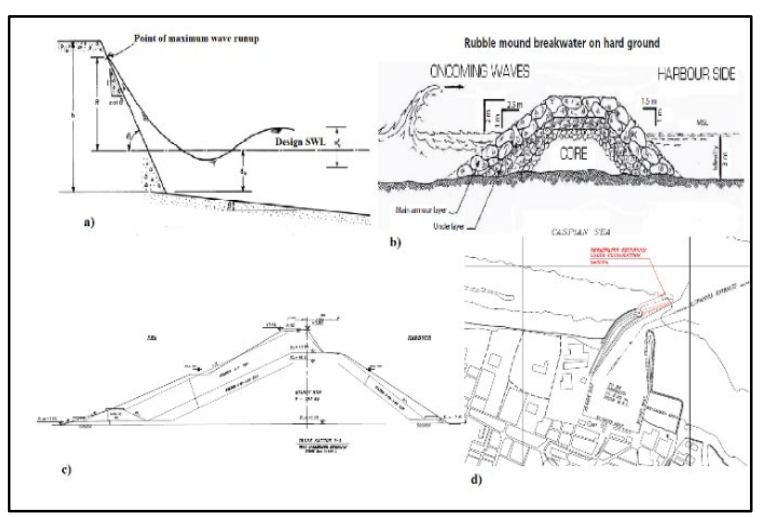

Figure 2. (a) Schematic of wave runnup (Center 1973) (b) wave approaching to a rubble mound breakwater, (c) Nowshahr breakwater cross-section, (d) Location of breakwater arms considering Caspian. 
In Figure 3, Caspian Sea including Iran's main ports has been presented plus Nowshahr breakwater arms Sea.

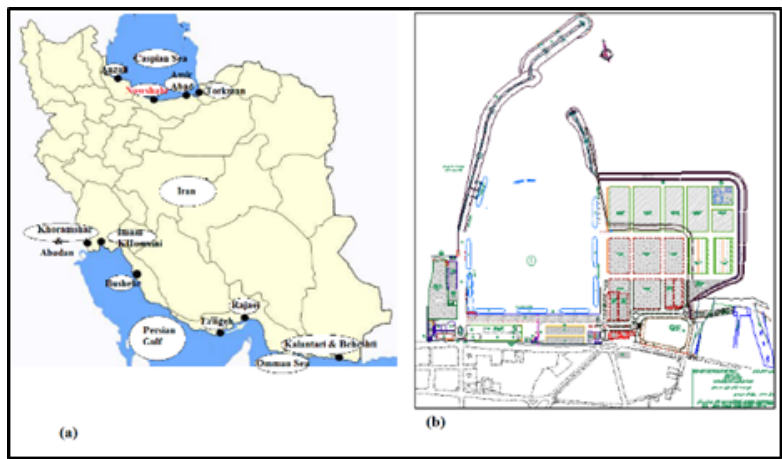

Figure3. (a) Caspian Sea + some important ports of Iran, (b) Nowshahr breakwater.(Sakhaee and Khalili 2020)

The main reason of breakwaters construction is to create a calm situation inside the harbor pool. But as soon as having the breakwater installed sedimentation and erosion occurs hence the consideration of sedimentation problems should also be considered in design phase. (Battjes and Janssen 1978, Ren 1986, Holthuijsen, Booij et al. 1989 Warren and Bach 1992, Valizadeh and Kolahdoozan 2011, Dibajnia, Soltanpour et al. 2012, Sakhaee 2020, Sakhaee 2020, Sakhaee and Khalili 2020) Entrance channel for some of the most important ports of Iran has been presented. (Figure 4.)

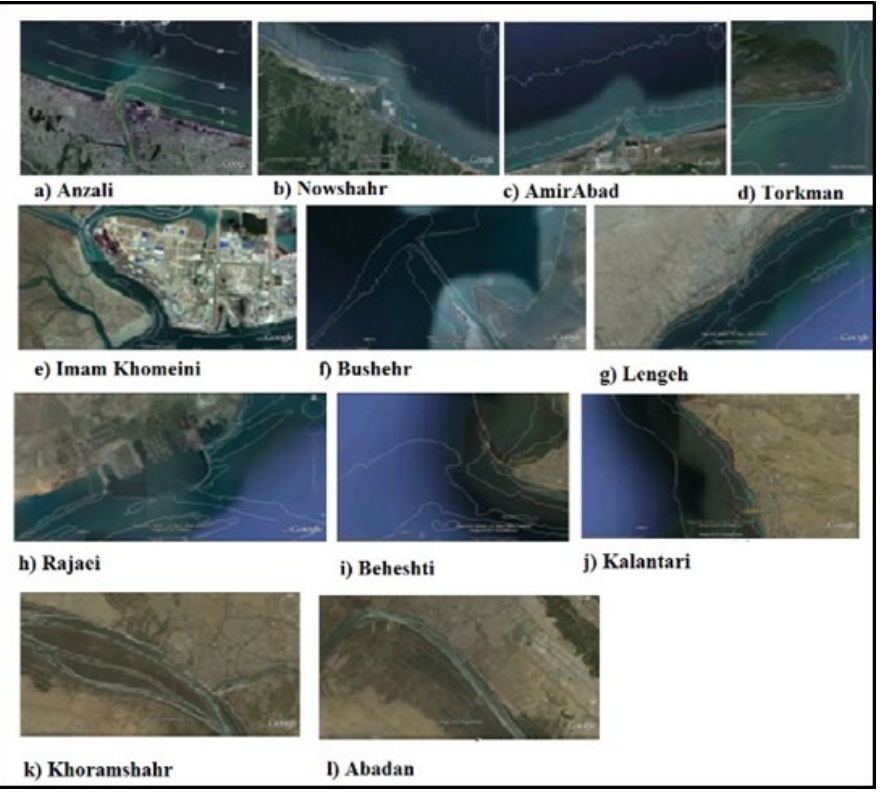

Figure 4. Access and entrance channels of some important ports of Iran for sedimentation and dredging purpose.

\section{Materials and Method}

\subsection{Available data}

Data used in this study includes bed slope of the shore in front of the breakwater, wave height, water depth, tidal range, frequency of the waves, water depth at structure toe, breakwater slope at the runup section which are all have been provided in table 1 below.

Table 1. Breakwater Specifications

\begin{tabular}{llccccc}
\hline $\begin{array}{l}\text { Wave } \\
\text { Height } \\
(\mathrm{m})\end{array}$ & $\begin{array}{l}\text { Frequency } \\
(\mathrm{Sec})\end{array}$ & $\begin{array}{c}\text { Water } \\
\text { Depth } \\
(\mathrm{m})\end{array}$ & $\begin{array}{c}\text { Water } \\
\text { Depth at } \\
\text { toe }(\mathrm{m})\end{array}$ & $\begin{array}{c}\text { Bed } \\
\text { Slope } \\
(\mathrm{m} / \mathrm{m})\end{array}$ & $\begin{array}{c}\text { Tidal } \\
\text { range } \\
(\mathrm{m})\end{array}$ & $\begin{array}{c}\text { Runup } \\
\text { Slope(m/m) }\end{array}$ \\
\hline 4 & 12 & 8 & 7.5 & 0.02 & 2.5 & $1: 2.5$ \\
\hline
\end{tabular}

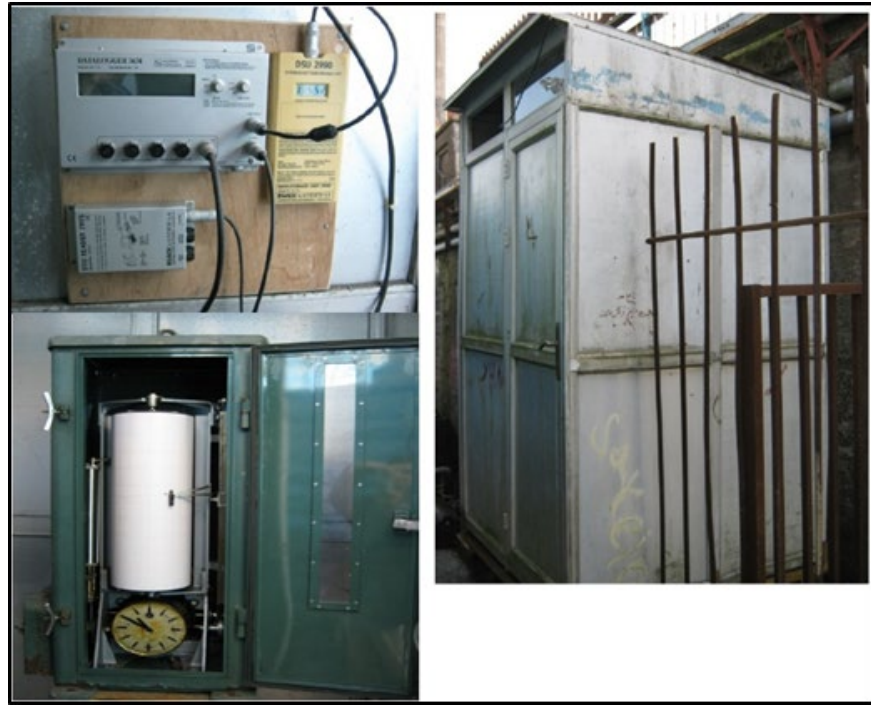

Figure 5. Water level measurement facilities at Anzali Port.

\subsection{Runup height calculations}

In this study a wave with the height of $4 \mathrm{~m}$ at the water depth of 8 meters has been considered while the water depth at the breakwater toe is 7 meters. Two scenarios have been investigated for tide and ebb modes. Based on shore protection manual for tidal mode calculation a safety factor of half of tidal range has been added to water depth and respectively for ebb mode half of tidal range subtracted from water depth.(Manual 1984) Due to shore protection manual breaking criteria in shallow water is equal to the ratio of breaker height to breaking depth. When a wave moves towards the shore into the shoaling water, the limiting steepness is a function of both relative depth $\frac{d}{\mathrm{~L}}$ and beach slope. A deep-water wave enters shallow water and proceed until breaking happen.

$\frac{H_{b}}{d_{b}}=0.78,(1)($ Manual 1984)

This depth is called breaking depth. Probability of breaking is higher at the ebb mode in comparison to tidal mode (Manual 1984).

In shallow water:

Wave breaking criteria.

1. $\mathrm{d} 1=8+\left(\frac{2.5}{2}\right)=9.25 \mathrm{~m}$ (Tide). (2)

2. $\mathrm{d} 2=8-\left(\frac{2.5}{2}\right)=6.75 \mathrm{~m}$ (Ebb). (3)

Calculation of $\frac{R}{H_{0}^{\prime}}$ to estimate the runup coefficient. SPM(Manual 1984, Box 1994, Engineers 2002)

$\frac{\mathrm{d}}{\mathrm{L}_{0}}=\frac{2 \Pi \mathrm{d}}{\mathrm{g} * T^{2}}=\frac{2 \Pi * 9.25}{9.81 * 8^{2}}=0.093$. (4)

For $\frac{\mathrm{d}}{\mathrm{L}_{0}}=0.093 \quad \frac{H}{H_{0}^{\prime}}=0.9391$. (5) $\quad H_{0}^{\prime}=4.26 \mathrm{~m}$. (6)

And $\frac{H_{0}^{\prime}}{\mathrm{g} * T^{2}}=\frac{4.26}{9.81 * 8^{2}}=0.0068 .(7)$

Two cycles of interpolation have been applied. First is internal interpolation and presented in table 2 below.

Using the depth at the structure toe ds $=7 \mathrm{~m}$ 1.64 (8)

For $\frac{\mathrm{d}_{\mathrm{s}}}{H_{0}^{\prime}}=0.8$ 
Table 2. Runup first interpolation

Runnp interpolation based on water depth at toe/ Unrefracted deep-water height

$\begin{array}{cccc}\frac{\mathrm{d}_{\mathrm{s}}}{H_{0}^{\prime}} & 0.8 & 0.8 & 0.8 \\ \frac{H_{0}^{\prime}}{\mathrm{g} * T^{2}} & 0.0062 & 0.0068 & 0.0078 \\ \frac{R}{H_{0}^{\prime}} & 1.8 & 1.73 & \\ & & & 1.6\end{array}$

Second interpolation is for $\frac{\mathrm{d}_{\mathrm{s}}}{H_{0}^{\prime}}=2$

Table 3. Second Runup interpolation

\begin{tabular}{ccc}
\hline Runnp interpolation based on water depth at toe/ Unrefracted \\
deep-water height
\end{tabular}

Table four shows the final value of interpolation which is the uncorrected value or runup.

Table 4. Runup interpolation results

\begin{tabular}{cccc}
\hline \multicolumn{4}{c}{$\begin{array}{c}\text { Runnp interpolation based on water depth at toe/ } \\
\text { Unrefracted deep-water height }\end{array}$} \\
\hline$\frac{\mathrm{d}_{\mathrm{s}}}{H_{0}^{\prime}}$ & 1.64 & 1.64 & 1.64 \\
$\frac{H_{0}^{\prime}}{\mathrm{g} * T^{2}}$ & 0.8 & 1.64 & 2 \\
$\frac{R}{H_{0}^{\prime}}$ & 1.73 & & 1.91 \\
& & 1.86 & \\
\end{tabular}

The uncorrected runup has been calculated as below.

$\mathrm{R}=1.86^{\star} H_{0}^{\prime}$. (9)

$\mathrm{R}=1.86 *(4.26)=7.92 \mathrm{~m}$

To calculate the real runup value two set of adjusting coefficients are needed. First is small scale coefficient which is an increasing coefficient and the second one is an increasing safety factor coefficient for quarry stone materials. Interpretation of these two factors is based on the logic of overestimating the small size coefficient and underestimating the material strength both to increase the safety factor of breakwater structure.

small scale coefficient

$\tan \theta=\frac{1}{2.5}=0.4$. (10) $\quad \mathrm{k}=1.17$

$\mathrm{R}=1.17 *(7.92)=9.26 \mathrm{~m}$

For Quarry stone armor material:

$r=\frac{R_{\text {rough slope }}}{R_{\text {smooth slope }}}$ From Fig 7_20 SPM

For $\frac{H_{0}^{\prime}}{\mathrm{g} * T^{2}}=0.0068 \approx 0.007, \frac{\mathrm{d}_{\mathrm{s}}}{H_{0}^{\prime}}>3$
$R_{\text {rough }}$ for $3=0.78$ then for $1.64=?=0.426$

$R_{\text {smooth }}$ for $3=1.75$ then for $1.64=?=0.956$

$\underline{R_{\text {rough slope }}}=0.426 / 0.956=0.445$.

$\mathrm{R}_{\text {smooth slope }}$

The reduction coefficient has been used to apply the void effects which are available between the interface of breakwater structure and waves as well as breakwater consisting materials.

Final Runup $=\mathrm{r}^{*} \mathrm{k}\left(H_{0}^{\prime}\right)=(0.445) *(1.17) *(7.92)=4.12 \mathrm{~m} .(12)$

This runnup is the base of free board calculation which considered to be one of the stability factors in terms of breakwater structural behavior.

Crest Elevation $=\mathrm{R}+\mathrm{d}_{\mathrm{s}}+$ Free board

\subsection{Cross sectional design}

Tidal mode

$\frac{\mathrm{d}}{\mathrm{L}_{0}}=\frac{2 \Pi \mathrm{d}}{\mathrm{g} * T^{2}}=\frac{2 \Pi * 9.25}{9.81 * 8^{2}}=0.093$

For $\frac{\mathrm{d}}{\mathrm{L}_{0}}=0.093$

$\frac{H}{H_{0}^{\prime}}=0.9391 \quad H_{0}^{\prime}=4.26 \mathrm{~m}$

And $\frac{H_{0}^{\prime}}{\mathrm{g} * T^{2}}=4.26 /(9.81 * 82)=0.0068 \approx 0.007, \mathrm{~m}=0.02$

$\frac{\mathrm{H}_{\mathrm{b}}}{H_{0}^{\prime}}=1.75$

$\mathrm{Hb}=7.469 \mathrm{~m}$

$\frac{H_{b}}{\mathrm{~g} * T^{2}}=0.01189 \approx 0.012, \mathrm{~m}=0.02 \quad \frac{d_{b}}{H_{b}}=1.32$

$\frac{H_{b}}{d_{b}}=0.757<0.78 \quad$ Non-breaking wave

2.2.2. Ebb mode

$\frac{\mathrm{d}}{\mathrm{L}_{0}}=\frac{2 \Pi \mathrm{d}}{\mathrm{g} * T^{2}}=\frac{2 \Pi * 6.75}{9.81 * 8^{2}}=0.067$

For $\frac{\mathrm{d}}{\mathrm{L}_{0}}=0.067 \quad \frac{\mathrm{H}_{\mathrm{b}}}{\mathrm{H}_{0}^{\prime}}=0.9772$

$H_{0}^{\prime}=4.1 \mathrm{~m}$

And $\frac{H_{0}^{\prime}}{\mathrm{g} * T^{2}}=4.1 /(9.81 * 82)=0.0065 \mathrm{~m}=0.02$

$\frac{\mathrm{H}_{\mathrm{b}}}{H_{0}^{\prime}}=1.06, \mathrm{Hb}=4.35 \mathrm{~m}$

$\frac{H_{b}}{\mathrm{~g} * T^{2}}=0.007, \mathrm{~m}=0.02$

$\frac{d_{b}}{H_{b}}=1.25$

\section{Results}

Hudson stability formula is driven from the vertical balance of structural blocks based on their free body diagram in contact with approaching waves including both stabilizer force such as weigh and destabilizer forces such as drag and uplift. (Figure .6) Based on Hudson equation.(Feuillet and Sabaton 1980, Tørum 1994, Hald and Burcharth 2001, Helgason, Burcharth et al. 2001, Melby 2005, Dibajnia, Soltanpour et al. 2012, Güler 2014, Guler, Ergin et al. 2014, AnielQuiroga, Vidal et al. 2018)

$$
\mathrm{W}=\frac{\Upsilon_{\mathrm{S}} \mathrm{H}^{3}}{\mathrm{~K}_{\mathrm{D}}(\mathrm{S} . \mathrm{G} .-1)^{3} * \operatorname{Cot} \theta}
$$

In this equation $\mathrm{W}$ is the design weight of the riprap armor, $\Upsilon_{\mathrm{S}}$ is materials specific weight, $\mathrm{H}$ is the design wave height at the toe of the structure, $K_{D}$ is a dimensionless stability coefficient, deduced from laboratory experiments for different kinds of armor blocks, S.G. specific gravity and $\theta$ is the angle of revetment measured form the horizontal plane. 


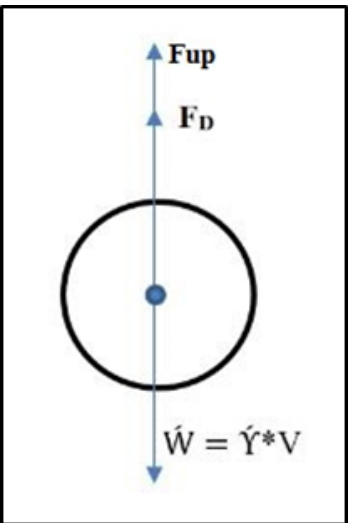

Figure 6. Free body diagram and applied forces

\subsection{Tidal case}

$\frac{\mathrm{H}_{\mathrm{b}}}{\mathrm{d}_{\mathrm{b}}}=0.757<0.78$

Non-breaking wave (Center 1973)

Good condition uses large $\mathrm{k}_{\mathrm{D}}$

Considerations:

Armor unit: Quarry stone, Rough angular, N=2, Placement: Random, For structure Trunk

Non-breaking condition wave

$\mathrm{K}_{\mathrm{D}}=4$

For structure Head

$\operatorname{Cot} \theta=2 \quad K_{D}=2.8$

$\operatorname{Cot} \theta=2.5 \quad \mathrm{~K}_{\mathrm{D}}=2.55$

$\operatorname{Cot} \theta=3 \quad K_{D}=2.3$

Layer coefficient $\mathrm{K} \Delta=1$

Porosity $=37 \%$

$\gamma_{s}=25.9 \mathrm{KN} / \mathrm{m} 3$

$\gamma_{w}=9.81 \mathrm{KN} / \mathrm{m} 3$

S.G. $=2.64$

$\Delta=2.64-1=1.64$

$\mathrm{W}_{\mathrm{TRUNK}}=(25.9 * 43) /(4 * 1.643 * 2.5)=37.6 \mathrm{KN}=3.76$ ton

$\mathrm{W}_{\mathrm{HEAD}}=(25.9 * 43) /(2.55 * 1.643 * 2.5)=58.9 \mathrm{KN}=5.89$ ton

\subsection{Ebb case}

$\frac{H_{b}}{d_{b}}=0.8>0.78 \quad$ breaking wave

Bad condition uses Small kD

For Trunk $\mathrm{K}_{\mathrm{D}}=2$

For Head

Cot $\theta=2 \quad K_{D}=2.6$

$\operatorname{Cot} \theta=2.5 \quad K_{D}=1.95$

$\operatorname{Cot} \theta=3 \quad K_{D}=1.3$

$\mathrm{W}_{\text {TRUNK }}=(25.9 * 43) /(2 * 1.643 * 2.5)=75.15 \mathrm{KN}=7.5$ ton

$\mathrm{W}_{\text {HEAD }}=(25.9 * 43) /(1.95 * 1.643 * 2.5)=77 \mathrm{KN}=7.7$ ton.

In this section two severe conditions of tidal and ebb scenarios have been evaluated for both trunk and head at breaking and non-breaking wave conditions based on shore protection manuals which are compatible with the intuitional results of possible head and trunk weight regarding tidal and ebb scenarios.

\section{Conclusion}

Based on results, weight of the breakwater head on both scenarios are higher than the trunk. Breakwater head is in direct contact with the waves hence should be stronger and heavier in comparison to the trunk to be able to reduce the energy of approaching waves. Base on Hudson equation Small $\mathrm{K}_{\mathrm{D}}$ values may use to reduce the armor materials weight in good conditions, and good conditions has been defined to be considered for: more stable conditions, structure trunk, Non-breaking wave and, finally uniform replacement of materials. Respectively in bad situation by increasing the $\mathrm{K}_{\mathrm{D}}$ values stability of armor structure is guaranteed. Bad condition has been defined as: less stable, structure head, breaking wave and, materials Random replacement. Design of breakwaters, groins and any other coastal protection structure should follow up a meticulous design criterion which include the design of cross sections as well as severe conditions to mitigate damages at the time of water crisis. As presented in this study a step-by-step design procedure has been developed to consider the runup derivation through cycles of interpolation and followed by two design configurations based on domestic data available at the construction site. The results showed that in either case of breaking and non-breaking wave conditions breakwater head has the priority in design because it should tolerate the momentum of encountering waves and dampening their energies while directing them towards breakwater trunk.

\section{Nomenclature}

$\mathrm{H} /\left(\mathrm{gT}^{2}\right)$ : dimensionless wave steepness.

$\mathrm{d} /\left(\mathrm{gT}^{2}\right)$ : dimensionless water depth.

$\mathrm{H}_{0}^{\prime}$ : unrefracted deep-water height.

$\gamma_{s}:$ Materials specific weight.

$\gamma_{w}$ : Water specific weight.

S.G.= specific gravity.

\section{Declaration of Conflict of Interests}

The author declares that there is no conflict of interest. They have no known competing financial interests or personal relationships that could have appeared to influence the work reported in this paper.

\section{References}

[1.] Aniel-Quiroga, İ., C. Vidal, J. L. Lara, M. González and Á. Sainz (2018). "Stability of rubble-mound breakwaters under tsunami first impact and overflow based on laboratory experiments." Coastal Engineering 135: 39-54.

[2.] Battjes, J. A. and J. Janssen (1978). Energy loss and set-up due to breaking of random waves. Coastal Engineering 1978: 569-587.

[3.] Box, P. (1994). "Shore protection manual."

[4.] Center, C. E. R. (1973). Shore protection manual, US Army Coastal Engineering Research Center.

[5.] Dentale, F., G. Donnarumma and E. P. Carratelli (2014). Rubble mound breakwater: run-up, reflection and overtopping by numerical 3D simulation. From Sea to Shore-Meeting the Challenges of the Sea: (Coasts, Marine Structures and Breakwaters 2013), ICE Publishing.

[6.] Dibajnia, M., M. Soltanpour, F. Vafai, S. M. H. J. Shoushtari and A. Kebriaee (2012). "A shoreline management plan for Iranian coastlines." Ocean \& coastal management 63: 1-15.

[7.] Engineers, U. A. C. O. (2002). "Coastal Engineering Manual. Engineer Manual 1110-2-1100." US Army Corps of Engineers, Washington, DC.

[8.] Feuillet, J. and M. Sabaton (1980). Stability of rubble mound breakwater. Coastal Engineering 1980: 1988-2002. 
[9.] Güler, H. G. (2014). A Comparative study on the design of rubble mound breakwaters, MSc. Thesis, Middle East Technical University, Ankara, Turkey.

[10.] Guler, H. G., A. Ergin and G. Ozyurt (2014). "A Comparative Study on the Stability Formulas of Rubble Mound Breakwaters." Coastal Engineering: 2.

[11.] Hald, T. and H. Burcharth (2001). An alternative stability equation for rock armoured rubble mound breakwaters. Coastal Engineering 2000: 1921-1934.

[12.] Helgason, E., H. F. Burcharth and J. r. B. Beck (2001). Stability of rubble mound breakwaters using high density rock. Coastal Engineering 2000: 1935-1945.

[13.] Holthuijsen, L., N. Booij and T. Herbers (1989). "A prediction model for stationary, short-crested waves in shallow water with ambient currents." Coastal engineering 13(1): 23-54.

[14.] Hur, D.-S., W.-D. Lee and W.-C. Cho (2012). "Characteristics of wave run-up height on a sandy beach behind dual-submerged breakwaters." Ocean Engineering 45: 38-55.

[15.] Irtem, E., E. Seyfioglu and S. Kabdasli (2011). "Experimental investigation on the effects of submerged breakwaters on tsunami run-up height." Journal of Coastal Research: 516-520.

[16.] Lynett, P. J., T.-R. Wu and P. L.-F. Liu (2002). "Modeling wave runup with depth-integrated equations." Coastal Engineering 46(2): 89-107.

[17.] Manual, S. P. (1984). "Coastal engineering research center." Dept. of the Navy, Waterways Experiment Station, Vickburg, MS.

[18.] Medina, J. R. (1999). Wind effects on runup and breakwater crest design. Coastal Engineering 1998: 1068-1081.

[19.] Melby, J. A. (2005). Breakwater and revetment armor stability, Engineer Research and Development Center Vicksburg Ms Coastal and Hydraulics Lab.

[20.] Muttray, M., H. Oumeraci and E. t. Oever (2007). Wave reflection and wave run-up at rubble mound breakwaters. Coastal Engineering 2006: (In 5 Volumes), World Scientific: 4314-4324.

[21.] Ren, M. (1986). "Comprehensive investigation of the coastal zone and tidal land resources of Jiangsu Province." Beijing: China Ocean Press 5: 1 .

[22.] Sakhaee, F. (2020). "Bankfull discharge estimation for Fishpot Creek." Technium: Romanian Journal of Applied Sciences and Technology 2(5): 74-91.

[23.] Sakhaee, F. (2020). "Steady and unsteady flow simulation with SRH-2D." Journal of Ocean Engineering and Science.

[24.] Sakhaee, F. and F. Khalili (2020). "Sediment pattern \& rate of bathymetric changes due to construction of breakwater extension at Nowshahr port." Journal of Ocean Engineering and Science.

[25.] Tørum, A. (1994). "Wave-induced forces on armor unit on berm breakwaters." Journal of waterway, port, coastal, and ocean engineering 120(3): 251-268.

[26.] Valizadeh, D. and M. Kolahdoozan (2011). "Reducing Sedimentation in Riverine Harbors Using Current Deflecting Wall." International Journal of Maritime Technology 6(12): 1-15.

[27.] Warren, I. and H. K. Bach (1992). "MIKE 21: a modelling system for estuaries, coastal waters and seas." Environmental Software 7(4): 229-240.

\section{How to Cite This Article}

Sakhaee, F., Wave Runup for Nowshahr Breakwater at Tide and EBB Scenarios, Brilliant Engineering, 4(2021), 10-14.

https://doi.org/10.36937/ben.2021.004.003 